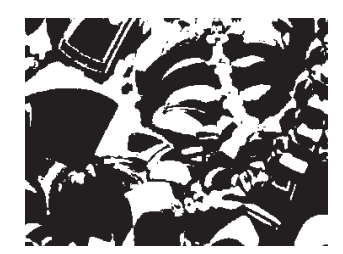

https://doi.org/10.5559/di.27.4.06

\title{
TWITTER AS A POLITICAL TOOL IN EU COUNTRIES DURING THE ECONOMIC CRISIS: A COMPARATIVE TEXT-MINING ANALYSIS
}

Tjaša REDEK

Faculty of Economics, University of Ljubliana, Ljubliana

Uroš GODNOV

Faculty of Management, University of Primorska, Koper

UDK: 004.773:32(4-6EU)

$81 ' 322$

Izvorni znanstveni rad

Primlieno: 19. 8. 2017.

This paper analyses the use of Twitter among politicians, in particular with regards to whether it was actively used during the economic crisis to promote economic agendas or rather merely to inform people. Forty-three thousand tweets of EU15 governments were collected, analysed using qualitative data analysis (text mining) and computational linguistics, using $R$ statistical packages, and interpreted. The results show that Twitter is used primarily to inform. Only in selected cases was the tool also used to more actively promote economic agendas. This article contributes to the field of political communication by providing, to the best of our knowledge, a broad analytical and comparative overview of Twitter activity for political purposes in Europe using text-mining methods.

Keywords: Twitter, politics, promotion of reforms, computational linguistics, text mining, cross-country analysis

$\square$ Tjaša Redek, Faculty of Economics, University of Ljubliana, Kardeljeva pl. 17, SI-1000 Ljubljana, Slovenia.

E-mail: tjasa.redek@ef.uni-li.si

\section{INTRODUCTION}

Modern technology has changed the face of communication immensely (e.g. Brants \& Voltmer, 2011). However, for what do politicians actually use modern technologies? How relevant are blogs, Facebook, and Twitter as tools for promoting polit- 
DRUŠ. ISTRAŽ. ZAGREB GOD. 27 (2018), BR. 4, STR. $691-711$

REDEK, T., GODNOV, U.: TWITTER AS A... ical ideas? Do politicians use them more as a tool to inform or also to push an agenda, or promote an idea?

'Four more years' by Barack Obama was the 'tweet of 2012'. This short, yet very effective set of 13 letters became the most communicated tweet ever (Twitter, 2012). Today, Twitter is, alongside other social media (Facebook, Instagram, Snapchat, etc.), one of the most important communication and promotion media. The rising importance of Twitter was best summarized by President Trump, who said: 'Without the tweets, I wouldn't be here...' (in Financial Times, in Twiplomacy, 2017).

The purpose of this article is to examine the use of Twitter as a tool of political communication of governments in the EU15 countries. We primarily examine whether Twitter was used as a tool to actively promote political programmes or ideas during the economic crisis. For example, in all countries, painful economic reforms aimed at fiscal consolidation were implemented. According to Grossman and Helpman (2001), what is unpopular among voters is also unpopular among politicians due to the impact on their re-election potential. In such times, governments must find broader support to successfully pass the reforms (during voting). Was Twitter used in this context as an additional tool to promote the need for reforms?

First, we hypothesise that due to the nature of its messages (shortness), and because it is the most specific, least spread, and youngest of the technologies, Twitter is used as a tool of communication by politicians, but primarily to inform and not actively promote political views or economic agendas. Second, we expect the tweets to be relatively neutral from the perspective of the sentiments. Third, we hypothesise that the extent of Twitter 'promotional' use also depends on the size of the 'Twitter market', which is also related to the general internet culture of the country. Various text-mining methods were used to answer these questions.

This article first provides a short theoretical motivation to the empirical research part, placing Twitter among other tools of political communication. Second, data about internet penetration and the use of social media across the EU are presented. Third, the methodology is described, followed by the presentation and discussion of results.

This article makes several original contributions. First, to the best of our knowledge, such a comparative analysis of the use of Twitter among government officials has not yet been conducted. Second, the analysis of the political use of Twitter on the part of the government as a tool of promotion of political ideas has also not yet been studied at a comparative level. Third, it illustrates the use of text mining in political communication analyses. 


\section{Web 2.0, social networks, and political promotion}

The media has long been perceived as being central to democracy (Dahlgren, 2014). In the past, politicians' communication machines had significant influence on daily discussions, but the situation has changed (Merrill, Latham, Santalesa, \& Navetta, 2011). The media no longer spreads news; on the contrary, now it tells you what to think (Greenfield, 2013)

The rise of the internet and social media allows politicians to be constantly present and much closer to voters, who are now being addressed through the web; web tools allow direct communication with voters and their representatives, programmes are being promoted, etc. (Auvinen, 2011). In addition, an individual can be actively involved, consult politicians or party representatives, get their direct feedback and thus strengthen sympathy for the party.

Communication is becoming increasingly more direct, but at the same time less programmatic, as Hofmesiter and Grabow (2011) claim. The presence of political parties/public institutions/officials on the web has become standard: political parties have their own web pages, blogs, Facebook pages and, in most cases, also Twitter (e.g. Vesnic-Alujevic, 2013, for the EU; Smith, 2011, for the USA). Social media, including Twitter, is being used either in government-to-citizen relations or government-to-government relations (e.g. in Korea it has been shown that it strengthens government-to-government relations, Khan, Yoon, Kim, \& Park, 2014).

\section{The 'market': The use of internet and social media (Twitter) in the EU}

The use of Twitter and other social media for political promotion likely depends on the size and characteristics of the target market. According to InternetWorld Stats (2016), over five hundred million EU28 citizens use the internet, which represents a $79.3 \%$ penetration rate (Table 1). Both internet and social media use in Europe, especially in the more developed EU15, are very high. Generally, internet penetration in the EU15 is high and even exceeds 90\% in Finland, Denmark, the Netherlands, Sweden, the UK, and Luxemburg. In 2015, it was lowest in Italy, where the internet is used by $62 \%$ of the population, and in Greece, where 63\% use it. The low penetration rate in these two countries can be linked to their lower economic development (Italy in the southern regions) and consequently poorer infrastructural development as well as purchasing power.

While social media are popular across the EU, they are least popular in Germany and Austria and in most of Italy and Greece. Social media is naturally the most popular among the young, primarily 16-25 year-olds, but the rest are not far behind (EMarketer, 2013, Table 1). 
(1) TABLE 1 Internet and social media in the EU15
Table 1 presents data on general internet use, Facebook and Twitter use in the EU15. Facebook is the predominant social media globally and in the EU15 (GlobalWebIndex, 2013).

\begin{tabular}{|c|c|c|c|c|c|c|c|}
\hline & 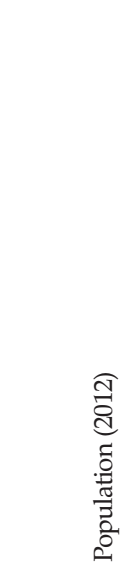 & 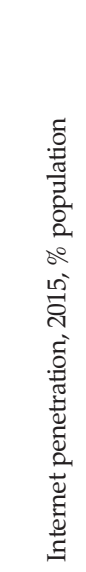 & 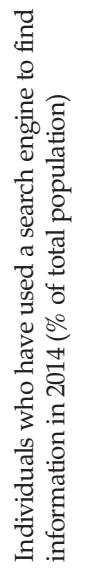 & 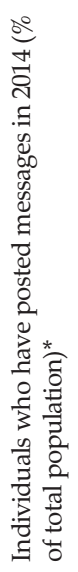 & 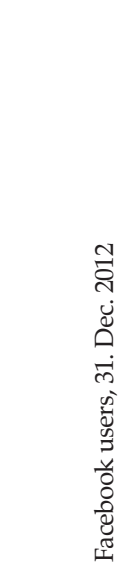 & 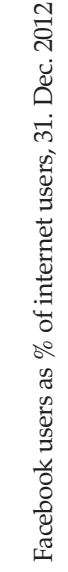 & 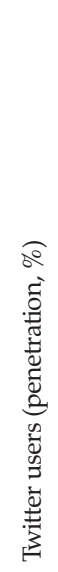 \\
\hline Austria & $8,219,743$ & $83.1 \%$ & 81 & 45 & $2,915,240$ & 44.4 & na \\
\hline Belgium & $10,438,353$ & $85.0 \%$ & 92 & 63 & $4,922,260$ & 58.0 & $2.2 *$ \\
\hline Denmark & $5,543,453$ & $96.0 \%$ & 83 & 29 & $3,037,700$ & 60.9 & $4.8^{*}$ \\
\hline Finland & $5,262,930$ & $93.5 \%$ & 76 & 26 & $2,287,960$ & 48.6 & na \\
\hline France & $65,630,692$ & $83.8 \%$ & 62 & 39 & $25,624,760$ & 49.1 & 2.1 \\
\hline Germany & $81,305,856$ & $88.4 \%$ & 73 & 41 & $25,332,440$ & 37.5 & na \\
\hline Greece & $10,767,827$ & $63.2 \%$ & 81 & 31 & $3,845,820$ & 67.4 & na \\
\hline Ireland & $4,722,028$ & $82.5 \%$ & 62 & 38 & $2,183,760$ & 60.2 & na \\
\hline Italy & $61,261,254$ & $62.0 \%$ & 91 & 43 & $23,202,640$ & 64.8 & na \\
\hline Luxembourg & 509,074 & $94.7 \%$ & 92 & 40 & 227,520 & 49.2 & 11 \\
\hline Netherlands & $16,730,632$ & $95.5 \%$ & 81 & 35 & $7,554,940$ & 48.6 & 26 \\
\hline Portugal & $10,781,459$ & $67.6 \%$ & 65 & 39 & $4,663,060$ & 78.4 & na \\
\hline Spain & $47,042,984$ & $76.9 \%$ & 90 & 56 & $17,590,500$ & 55.7 & 14 \\
\hline Sweden & $9,103,788$ & $94.6 \%$ & 92 & 54 & $4,950,160$ & 58.6 & na \\
\hline UK & $63,047,162$ & $91.6 \%$ & 86 & 47 & $32,950,400$ & 62.5 & 12 \\
\hline
\end{tabular}

* Individuals who have posted messages to chat rooms, newsgroups or an online discussion forum. Source: Eurostat, 2015, Internet World Stats, 2015 and Los Angeles Times, 2013. Those marked by * calculated from data by MVFGlobal, 2014.

The popularity of Twitter has increased dramatically. GlobalWebIndex (2013) estimated that in 200935.5 million people were active users of this social medium globally. However, from only Q2 to Q4 in 2012 the use increased by 40\%, making this social platform the one with the most substantial growth rate, exceeding even Facebook's. Twitter is slightly more popular among women and is predominantly used by the younger population (Beevolve, 2012). According to GlobalWebIndex (2013), the most common uses were to post comments about brands, use branded applications, and ask friends about other products. It was also increasingly used to organise events, buy products (links/discovery of a product), but in contrast was least popular for informing colleagues about their daily activities or commenting on them. 


\section{ANALYSIS}

\section{Research questions}

The purpose of this analysis is to examine the differences in the use of Twitter for political purposes in the EU15 countries. The period in question was marked by the economic crisis and unpopular reforms, and social media could be used to promote the latter. Specifically, the following research questions are addressed:

1) What are the prevailing purposes for which Twitter is used in political communication? Is it, due to the shortness of the text, used primarily to inform or is it also used to promote political views or, in our case, reform (economic) agendas?

2) In relation to the first question, is the nature of political communication via Twitter neutral or is it more coloured with views, strong opinions, stances, exhibiting non-neutral values of emotions?

3) Given that different countries are studied with different levels of development of the use of Twitter for political purposes, to what extent does the penetration of Twitter relate to the use and the nature of the use of it for political purposes?

\section{Methodology and sample}

Methodologically, the analysis relies on different methods of text mining, which are increasingly used in research, primarily in the analysis of social media and other user-generated content (e.g. Bahtar \& Muda 2016). The methods used can broadly be classified into two broader groups: (1) content analysis or topic modelling, and (2) sentiment analysis.

With regards to content analysis, we relied on two main methods: key-words analysis and latent Dirichlet allocation (LDA analysis). Key-words analysis is a simple method, but very effective, identifying key-words based on word stems. By definition, key-words summarise the text (Zhang et al., 2008). Topic modelling, in general, is according to Blei (2012) based on probabilistic mathematical modelling, which, using an iterative procedure helps determine the main themes in large volumes of extensive texts. LDA analysis, as an approach to topic modelling, is '[...] a way of automatically discovering topics that these sentences contain' (Chen, 2011) or a method of 'finding and tracing clusters of words' (topics) in the text (Posner, Wallace, \& Borovsky, 2012). It perceives any document as a collection of words, from which by checking linkages between words, it identifies main topics in the document.

Sentiment analysis was used to further assess the characteristics of political Twitter use, primarily to evaluate the general attitude of the text (or statements), whether it is positive, neutral or negative. This 'attitude', of course, results from a set of different impacts (general context, personal emotions or 
DRUŠ. ISTRAŽ. ZAGREB GOD. 27 (2018), BR. 4, STR. $691-711$

REDEK, T., GODNOV, U.: TWITTER AS A...

(1) TABLE 2

Data collection summary* general affective state of the writer/speaker at the time, the actual situation and its seriousness, personal attitude towards the problem, speaker's/writer's intent etc.) (DeHaaff, 2010). Sentiment analysis was done in $\mathrm{R}$, relying on the methodology of $\mathrm{Hu}$ and Liu (2004). A cumulative score for every tweet was calculated based on the number of positive and negative words in a selected tweet.

Data. To conduct the analysis, over 43,000 tweets from the official political accounts held by governments (prime ministers), presidents or ministers of the EU15 countries (and also the Twitter account of the EU itself, merely for illustration) were used (Table 2).

\begin{tabular}{|c|c|c|c|c|}
\hline & $\begin{array}{l}\text { Number of Tweets } \\
\text { in the analysis }\end{array}$ & $\begin{array}{l}\text { Period between } \\
\text { first and last Tweet }\end{array}$ & Accounts & Accounts held by \\
\hline Austria & 1537 & $\begin{array}{l}2011-01-31 \\
2014-01-24\end{array}$ & @MFA_Austria & Ministry of Foreign Affairs \\
\hline Belgium & 2774 & $\begin{array}{l}2012-10-28 \\
2014-01-27\end{array}$ & (a)dreynders & Prime Minister \\
\hline Denmark & 3216 & $\begin{array}{l}2010-01-26 \\
2014-01-27\end{array}$ & @vestager & Minister of Economy \\
\hline Finland & 1735 & $\begin{array}{l}2011-05-03 \\
2014-01-24\end{array}$ & $\begin{array}{l}@ \text { FinGovernment } \\
\text { @TPKanslia }\end{array}$ & $\begin{array}{l}\text { Prime Minister } \\
\text { Finnish President }\end{array}$ \\
\hline France & 3069 & $\begin{array}{l}2013-01-11 \\
2014-01-27\end{array}$ & @Elysee & French President \\
\hline Germany & 5652 & $\begin{array}{l}2011-05-03 \\
2014-01-27\end{array}$ & $\begin{array}{l}\text { @ AuswaertigesAmt } \\
\text { (a)RegSprecher }\end{array}$ & $\begin{array}{l}\text { For Angela Merkel Mi- } \\
\text { nistry of Foreign Affairs }\end{array}$ \\
\hline Greece & 1068 & $\begin{array}{l}2010-02-16 \\
2014-01-21\end{array}$ & @PrimeministerGR & Prime Minister \\
\hline Ireland & 2985 & $\begin{array}{l}2012-02-23 \\
2014-01-27\end{array}$ & $\begin{array}{l}@ \text { EamonGilmore } \\
@ \text { Merrionstreet }\end{array}$ & $\begin{array}{l}\text { Ministry of Foreign Affairs } \\
\text { Government }\end{array}$ \\
\hline Italy & 2586 & $\begin{array}{l}2012-01-11 \\
2014-01-27\end{array}$ & $\begin{array}{l}\text { @EnricoLetta } \\
\text { @Palazzo_Chigi } \\
\text { @QQuirinaleStampa }\end{array}$ & $\begin{array}{l}\text { Prime Minister } \\
\text { Government } \\
\text { President }\end{array}$ \\
\hline Luxembourg & \multicolumn{4}{|c|}{$\begin{array}{l}\text { The government, president, prime minister or ministry of foreign } \\
\text { affairs did not have a Twitter account (on January 27th, 2014). }\end{array}$} \\
\hline Netherlands & 4137 & $\begin{array}{l}2010-28-10 \\
2014-01-27\end{array}$ & $\begin{array}{l}@ \text { MinPres } \\
@ \text { Rijksoverheid }\end{array}$ & $\begin{array}{l}\text { Prime Minister } \\
\text { Government }\end{array}$ \\
\hline Portugal & 2485 & $\begin{array}{l}2008-11-11 \\
2014-01-24\end{array}$ & @presidencia & President of Portugal \\
\hline Spain & 3449 & $\begin{array}{l}2011-12-12 \\
2014-01-27\end{array}$ & @marianorajoy & Government \\
\hline Sweden & 3688 & $\begin{array}{l}2011-10-24 \\
2014-01-27\end{array}$ & $\begin{array}{l}\text { @.carlbildt } \\
\text { @SweMFA }\end{array}$ & $\begin{array}{l}\text { Minister of Foreign Affairs } \\
\text { Ministry of Foreign Affairs }\end{array}$ \\
\hline $\begin{array}{l}\text { United } \\
\text { Kingdom }\end{array}$ & 4869 & $\begin{array}{l}2010-06-24 \\
2014-01-27\end{array}$ & $\begin{array}{l}\text { @WilliamJHague } \\
\text { @Number10gov }\end{array}$ & $\begin{array}{l}\text { Ministry of Foreign Affairs } \\
\text { Prime Minister }\end{array}$ \\
\hline
\end{tabular}

* Where possible, the president and the prime minister were used. Where these two are not listed, but members of the government are used instead (like the minister of foreign affairs), either the president or the prime minister were not using Twitter. Only in the case of Luxemburg were we not able to identify an official governmental Twitter account. 
DRUŠ. ISTRAŽ. ZAGREB GOD. 27 (2018), BR. 4 STR. $691-711$

REDEK, T., GODNOV, U. TWITTER AS A...
Data was collected from Twitter accounts using Twitter API v1.1, which was in use in March 2013. Pure tweets were separated from retweets, URL links excluded and also words beginning with @ and \#. Clean tweets were exported to Excel.

Tweets were translated using Google Translate, which is considered adequate in providing comprehensive translations; reliability also increases with the simplicity of text (Aiken \& Balen, 2011; Coughlin, 2003) and tweets are very simple texts. In addition, the analysis is focused on keywords and not the sentences, providing an additional reason that Google Translate can be used. The text mining was conducted in R, using the TM package.

\section{RESULTS}

() TABLE 3

A selection of the 25 most common words in the tweets, their relative frequency (in $\%)$ and the total word count in the analysed tweets, highlighted words with economic content
What follows is the presentation of the results. We are mainly interested in what Twitter is being used for: primarily to inform, or was it also used to promote economic reforms in the period under investigation. Table 3 presents a summary of keywords for the EU15 members.

\begin{tabular}{|c|c|c|c|c|c|c|c|c|c|}
\hline $\begin{array}{l}\text { Austria } \\
(\mathrm{N}=13667)\end{array}$ & $\%$ & $\begin{array}{l}\text { UK } \\
(\mathrm{N}=47548)\end{array}$ & $\%$ & $\begin{array}{l}\text { Belgium } \\
(\mathrm{N}=16298)\end{array}$ & $(\%)$ & $\begin{array}{l}\text { Denmark } \\
(\mathrm{N}=31369)\end{array}$ & $(\%)$ & $\begin{array}{l}\text { Finland } \\
(N=12943)\end{array}$ & $(\%)$ \\
\hline Foreign & 1.57 & Today & 1.06 & Weather & 2.00 & Good & 1.80 & Minister & 3.54 \\
\hline Austria & 1.06 & Syria & 0.84 & Brussels & 1.55 & Day & 0.65 & Tpniinist & 2.43 \\
\hline Today & 0.93 & Minister & 0.81 & Belgium & 1.30 & Well & 0.58 & Finland & 2.21 \\
\hline Rights & 0.86 & Foreign & 0.73 & Syria & 0.78 & Way & 0.51 & Foreign & 1.58 \\
\hline Syria & 0.83 & Meeting & 0.64 & Belgian & 0.78 & Like & 0.47 & President & 1.13 \\
\hline Human & 0.75 & Support & 0.62 & Meeting & 0.74 & Debate & 0.44 & Prime & 1.09 \\
\hline Austrian & 0.73 & People & 0.58 & European & 0.62 & Thank & 0.42 & Visit & 0.99 \\
\hline Meeting & 0.72 & Prime & 0.57 & Minister & 0.56 & People & 0.42 & Stubb & 0.69 \\
\hline Council & 0.71 & Visit & 0.41 & Budget & 0.55 & Fashion & 0.41 & Finnish & 0.66 \\
\hline Minister & 0.68 & Help & 0.40 & Congratulations & 0.50 & Morning & 0.41 & Council & 0.65 \\
\hline Travel & 0.58 & Libya & 0.40 & Foreign & 0.49 & Work & 0.40 & Meeting & 0.63 \\
\hline Europe & 0.57 & Talks & 0.40 & Affairs & 0.48 & $\operatorname{Tax}$ & 0.39 & Government & 0.61 \\
\hline Vienna & 0.51 & Ministers & 0.38 & Council & 0.45 & Think & 0.39 & Ministers & 0.57 \\
\hline Conference & 0.50 & World & 0.37 & Rain & 0.40 & Government & 0.37 & Affairs & 0.56 \\
\hline Information & 0.40 & David & 0.35 & Good & 0.39 & Denmark & 0.36 & Development & 0.53 \\
\hline Ministry & 0.39 & President & 0.35 & World & 0.37 & Better & 0.33 & State & 0.53 \\
\hline Affairs & 0.36 & London & 0.35 & Sun & 0.37 & Time & 0.33 & European & 0.51 \\
\hline East & 0.33 & Great & 0.33 & Day & 0.35 & Radical & 0.32 & Cooperation & 0.50 \\
\hline Egypt & 0.33 & Good & 0.33 & Mission & 0.35 & Congratulations & 0.32 & Policy & 0.43 \\
\hline Day & 0.30 & Speech & 0.33 & Thank & 0.33 & Many & 0.32 & Security & 0.42 \\
\hline Ministers & 0.30 & Read & 0.32 & Standard & 0.33 & Great & 0.31 & Economic & 0.39 \\
\hline Discussion & 0.29 & Business & 0.32 & Snow & 0.30 & Growth & 0.31 & Met & 0.39 \\
\hline European & 0.29 & Watch & 0.32 & Europe & 0.29 & Thanks & 0.29 & Nordic & 0.39 \\
\hline Press & 0.27 & British & 0.32 & President & 0.28 & Home & 0.28 & Attend & 0.38 \\
\hline Sts & 0.27 & Work & 0.31 & Economic & 0.27 & Minister & 0.28 & Hautala & 0.36 \\
\hline
\end{tabular}

(Continued) 
(1) TABLE 3 (Continued)

\begin{tabular}{|c|c|c|c|c|c|c|c|c|c|}
\hline $\begin{array}{l}\text { France } \\
(\mathrm{N}=24062)\end{array}$ & $(\%)$ & $\begin{array}{l}\text { Greece } \\
(\mathrm{N}=7131)\end{array}$ & $(\%)$ & $\begin{array}{l}\text { Ireland } \\
(\mathrm{N}=24470)\end{array}$ & $(\%)$ & $\begin{array}{l}\text { Italy } \\
(N=20417)\end{array}$ & $(\%)$ & $\begin{array}{l}\text { Germany } \\
(\mathrm{N}=53590)\end{array}$ & $(\%)$ \\
\hline President & 4.24 & Prime & 5.59 & Minister & 1.41 & Council & 0.99 & Westerwelle & 1.92 \\
\hline Republic & 1.89 & Minister & 4.70 & Jobs & 1.20 & Ministers & 0.95 & Chancellor & 1.88 \\
\hline France & 1.29 & Samaras & 2.31 & Budget & 1.13 & Meeting & 0.81 & Merkel & 1.66 \\
\hline Hollande & 1.15 & Antonis & 2.17 & Ireland & 1.03 & Today & 0.78 & Travel & 0.74 \\
\hline Council & 1.12 & Meeting & 1.86 & Questions & 0.86 & President & 0.77 & Government & 0.58 \\
\hline Francois & 1.05 & Statement & 1.86 & Live & 0.62 & Italy & 0.69 & Foreign & 0.56 \\
\hline Press & 0.94 & Speech & 1.84 & Tanaiste & 0.61 & Press & 0.65 & Today & 0.55 \\
\hline Photos & 0.90 & Greece & 0.89 & Leaders & 0.57 & Napolitano & 0.63 & German & 0.53 \\
\hline Ministers & 0.82 & Ministers & 0.78 & Press & 0.56 & Government & 0.59 & Federal & 0.51 \\
\hline Conference & 0.66 & European & 0.75 & Conference & 0.52 & Monti & 0.46 & Europe & 0.49 \\
\hline Speech & 0.65 & President & 0.75 & People & 0.49 & Conference & 0.35 & Germany & 0.46 \\
\hline Government & 0.63 & Time & 0.72 & Noonan & 0.45 & Good & 0.35 & Security & 0.46 \\
\hline Interview & 0.61 & Country & 0.63 & Government & 0.42 & Time & 0.34 & Syria & 0.46 \\
\hline Find & 0.55 & Statements & 0.61 & Today & 0.40 & Release & 0.33 & Rights & 0.38 \\
\hline French & 0.55 & Conference & 0.56 & Dublin & 0.39 & Law & 0.31 & Conference & 0.36 \\
\hline European & 0.50 & Live & 0.54 & President & 0.36 & Work & 0.30 & Human & 0.35 \\
\hline Agenda & 0.48 & Council & 0.53 & Day & 0.32 & Statement & 0.29 & Council & 0.33 \\
\hline State & 0.43 & Today & 0.53 & Govt & 0.32 & Change & 0.29 & Visit & 0.31 \\
\hline Follow & 0.42 & Government & 0.51 & Plan & 0.32 & European & 0.27 & Minister & 0.31 \\
\hline Maintenance & 0.41 & Visit & 0.50 & Programme & 0.31 & Heres & 0.27 & Information & 0.30 \\
\hline Visit & 0.41 & Summit & 0.45 & Watch & 0.30 & Italian & 0.27 & Office & 0.29 \\
\hline Briefing & 0.40 & Change & 0.44 & Investment & 0.29 & Well & 0.27 & Press & 0.29 \\
\hline Sommetelysee ${ }^{* *}$ & 0.39 & House & 0.44 & Launch & 0.29 & Minister & 0.26 & Live & 0.29 \\
\hline Europe & 0.39 & Republic & 0.41 & Report & 0.29 & Right & 0.25 & Meeting & 0.27 \\
\hline Minister & 0.38 & Watch & 0.38 & Health & 0.28 & Think & 0.24 & Policy & 0.27 \\
\hline $\begin{array}{l}\text { Netherlands } \\
(\mathrm{N}=37821)\end{array}$ & $(\%)$ & $\begin{array}{l}\text { Portugal } \\
(\mathrm{N}=20759)\end{array}$ & & $(\%)$ & $\begin{array}{l}\text { Spain } \\
(\mathrm{N}=280\end{array}$ & & $(\%)$ & $\begin{array}{l}\text { Sweden } \\
(\mathrm{N}=35890)\end{array}$ & $(\%)$ \\
\hline Minister & 2.23 & President & & 1.12 & Press & & 2.93 & Today & 1.13 \\
\hline Netherlands & 1.13 & Site & & 1.09 & Nationa & & 2.00 & Sweden & 0.83 \\
\hline Government & 0.68 & Republic & & 0.54 & Mornin & & 1.94 & Good & 0.67 \\
\hline Today & 0.63 & Received & & 0.30 & Good & & 1.89 & Important & 0.65 \\
\hline Press & 0.58 & Silva & & 0.21 & Ministry & & 1.82 & Swedish & 0.63 \\
\hline Prime & 0.58 & Cavaco & & 0.20 & Preside & & 1.36 & Meeting & 0.62 \\
\hline Cabinet & 0.57 & Portugal & & 0.14 & Comms & nication & 1.33 & Stockholm & 0.62 \\
\hline State & 0.54 & Sent & & 0.88 & Bulletin & & 1.29 & Day & 0.58 \\
\hline European & 0.51 & Portuguese & & 0.75 & Availabl & & 1.26 & Syria & 0.54 \\
\hline Conference & 0.48 & Condolenc & ces & 0.69 & Rajoy & & 1.23 & World & 0.51 \\
\hline Secretary & 0.48 & Visit & & 0.68 & Confere & nce & 1.18 & President & 0.47 \\
\hline Council & 0.44 & Message & & 0.64 & Minute & & 1.18 & Talks & 0.46 \\
\hline Photo & 0.41 & Visited & & 0.62 & Meeting & & 1.14 & Ukraine & 0.41 \\
\hline Affairs & 0.39 & State & & 0.60 & Monclo & & 1.12 & Well & 0.41 \\
\hline Live & 0.38 & Met & & 0.56 & Ministe & & 1.07 & Europe & 0.37 \\
\hline Security & 0.35 & National & & 0.56 & Summa & & 1.03 & European & 0.36 \\
\hline Meeting & 0.33 & Inaugurate & & 0.49 & Govern & nent & 0.96 & Issues & 0.34 \\
\hline Economic & 0.33 & Day & & 0.47 & Agenda & & 0.96 & Discussions & 0.34 \\
\hline Foreign & 0.32 & Family & & 0.45 & Prime & & 0.85 & Council & 0.34 \\
\hline Ministers & 0.30 & Congratul & ated & 0.41 & Council & & 0.85 & Soon & 0.33 \\
\hline National & 0.29 & Counterpa & & 0.36 & State & & 0.83 & Welcome & 0.32 \\
\hline Social & 0.29 & Meeting & & 0.35 & Spain & & 0.82 & Great & 0.32 \\
\hline Day & 0.28 & Council & & 0.32 & Govern & nents & 0.80 & Security & 0.29 \\
\hline $\operatorname{Tax}$ & 0.28 & Minister & & 0.31 & Live & & 0.79 & Visit & 0.29 \\
\hline Schultz & 0.28 & European & & 0.28 & Tomorr & & 0.79 & Brussels & 0.28 \\
\hline
\end{tabular}

Notes:

* TPNiinistö - one of Twitter users. Tanaiste - deputy prime minister.

** Sommetelysee - Sommet de l'Elysée

Names and surnames of politicians kept (e.g. Cavaco. Hollande. Rajoy. etc.) 
DRUŠ. ISTRAŽ. ZAGREB GOD. 27 (2018), BR. 4 STR. $691-711$

REDEK, T., GODNOV, U.: TWITTER AS A...
The selection of the most common words in the analysed set is quite similar: words such as 'minister/government', 'meeting', 'speech', 'conference', 'council', and 'press' or similar substitutes are present. Words such as 'today', 'visit', 'debate', 'video', 'photo', 'statement', 'communication', 'talk', etc. are also very common. Only the Belgian official tweets often comment on things such as weather, which is related to their climate, where policy issues have also revolved around more extreme weather especially lately, as well as culturally important events (Belgium: a country study, 2013). To summarise, the overview of words gives the impression that Twitter is used primarily to inform.

To further analyse whether our initial keywords analysis does, in fact, provide us with the correct conclusion, we conducted a key-word-in-context analysis using $R$. The analysis confirmed the informative nature of Twitter usage in politics. Namely, among associations of higher strength, combinations like 'prime minister', 'President Obama', 'foreign minister', 'foreign affairs', 'meet' (someone, different names by different countries), 'human right', 'Syria embargo', 'travel warning', 'travel Egypt', 'budget support', 'budget reconciliation', 'mission began', and 'mission sent' were most common.

In all countries, as said, the main task of Twitter is primarily to inform people about activities, meetings, as well as laws passed, or discussed, and similar issues. Despite this common trait, the differences between countries are still evident. While Portugal is primarily informing followers about the activities ("President of the Republic will award Cristiano Ronaldo"), Danish, German, Irish, Italian, Belgian, Finnish, etc. are informative but more actively. For example, the Danish government Twitter account hails a programme for being accepted and thereby promotes its ideas ("Last stop on the nationwide tour: Herning. They have done a great programme for growth and innovative companies."). In addition to informing readers by using quotes from an event, German tweets also often indirectly push a message or promote an idea ("BM \#Westerwelle at Forum on Global Issues for \#food security in AA: action against hunger is also a commitment to peace and security."). A number of similar examples that summarise activities or inform readers about forthcoming activities but at the same time also push a specific agenda, praise the decisions, etc. are found in the majority of cases.

Overall, the key-words analysis shows that Twitter was used primarily to inform in the period of the economic crisis. The informative role of Twitter in the studied EU countries is also in line with the research for other countries. For example, Vongsoasup and Iijima (2016) find a similar situation in Thailand, where authors claim that it is used as an information- 
DRUŠ. ISTRAŽ. ZAGREB GOD. 27 (2018), BR. 4, STR. $691-711$

REDEK, T., GODNOV, U. TWITTER AS A... -disseminating tool and that the majority of tweets were informative and widely spread. Furthermore, Stieglitz and Dang-Xuan (2013) stress the role of Twitter as a platform for dissemination, whereas for political parties they also underscore the potential to actively stress opinions. Similarly, McGregor, Mourão, and Molyneux (2017) also emphasise the role of Twitter for political communication, and they investigated the role of Twitter in elections, where the debate is more focused on political stances. In our case, when focusing on governments and not political parties (that have to distinguish themselves and more distinctively take sides), more neutral communication is expected.

Given the increasing role of Twitter in political communication, we were interested in how the content of the tweets was related to the general economic situation. The economic crisis hit all of the EU countries, mostly the Baltic states, Finland and Slovenia (9-15\% decline). Greece was the hardest hit of the EU15. Severe decline was also felt by Ireland, primarily due to its banking crisis. Sweden, the UK, Germany, Spain, and Austria felt more pronounced declines in 2009 (4-6\%). However, in the majority of countries, the situation soon improved. The exceptions were Greece, Ireland, and Portugal, where the decline continued to be quite significant (Eurostat 2018). As a consequence, the economic policies implemented were more painful for the population (voters). For example, in Greece, the minimum wage was cut by $22 \%$, the state sector workforce was expected to be cut by 150,000 people by 2015, and social security was cut (Reuters 2012). In Ireland, according to a NERI (2013) study, austerity measures cut spending by 30 billion euros which was estimated to represent $18 \%$ of GDP. Portugal cut public sector wages to around $80 \%$; health, education and social security spending were cut, and public jobs eliminated (Oxfam, 2013).

In countries where the economic situation was worse, was Twitter also used for persuading the voters about the necessity of the unpopular measures? If so, primarily in Greece, Italy, Ireland, Portugal and Spain (PIIGS countries), economic content would have to be much more apparent than in other countries. In Table 3, the words that are directly linkable to economic problems among the 25 most common words are highlighted. It is evident that even in the most affected countries the primary purpose of tweeting was not to promote economic agendas. Although it is true that the keywords analysis shows that Greece, Ireland and Spain were most active in 'promoting' economic agendas or informing about economically related topics. Words that could be linked to the economic situation, are 'national', 'work', to a lesser extent also 'support' (to support a measure), while the rest of the words 
DRUŠ. ISTRAŽ. ZAGREB GOD. 27 (2018), BR. 4 STR. 691-711

REDEK, T., GODNOV, U.: TWITTER AS A... are linked to a number of informative statements. For example, Ireland praises investment ('New high-tech investment in Cork adds to "solid base for future job creation" - Sherlock'), sustainability of pension program ('No change to the State Pension for older people \#Budget14'), and tax stability, ('No increases in the $9 \%, 13.5 \%$ or $23 \%$ VAT rates in $2014-$ Noonan \#Budget14'). Spain stressed 'We try to forge ahead on a path neither easy nor pleasant, but we cannot avoid it because it is the only way to recovery'. Italy stressed additional funding ('CDM approved $€$ 6bn of European funds due, inter alia, youth employment, relocation unemployed, fight poverty, help schools'), and Greece stressed reforms ('Prime Minister: "We are moving in radical changes in 2011 in public administration, education, innovation, entrepreneurship" \#GRexports.'). Especially in Portugal, economic content was rare despite the economic distress.

However, 'economic' content is visible also in the cases of Finland and the Netherlands, Denmark, and Sweden (see also LDA results for a related discussion, Table 4). For example, the Dutch government said: 'Finally. Let's settle so we can provide money to children, youth, education, at risk and vulnerable...', while Sweden stressed their innovativeness and performance in the following two tweets "A century ago, \#Sweden was among the poorest nations in Europe. Today, it is a world leader in \#innovation." and "The \#Swedish economy is performing well in comparison with other Western nations. How come?". The same holds for Austrian and German tweets. For example, Germany stressed performance in the following tweets: "Economics Minister Rösler: German economy continues to grow. Good development in the labour market" and "Perspective for young Europeans: special program for young people, training / qualif. Find a job in Germany." In Austria and Germany, the ecological component was also quite strong (as in Denmark and Finland) (for example in Austria "Water and Energy Security are prerequisites for food security, StS Waldner at EZA Council in Brussels \#").

Following a detailed manual overview of tweets and keyword analysis, it can be said that Twitter was on average not actively used for the promotion of economic reform. Even in cases of more economic content in the tweets, these are still not 'promoting' economic agendas or reforms, but are again rather informative in nature, in this case, related more to economic results (selection of illustrative tweets done by authors).

To further analyse the content of Twitter messages, LDA (latent Dirichlet allocation) was used. The results for many countries revealed only the 'informative nature'; the only countries, in which, as identified by LDA analysis, economic content stood out in terms of topics were Denmark, Ireland, and 
DRUŠ. ISTRAŽ. ZAGREB GOD. 27 (2018), BR. 4, STR. $691-711$

REDEK, T., GODNOV, U. TWITTER AS A..

(1) TABLE 4

Results of the LDA

analysis: selected countries
Sweden (Table 4 presents LDA results for these countries, more economically oriented topics are highlighted). However, it should be noted that the presence of economic topics itself does not yet imply the 'promotion' of economic agendas and reforms. If these results are investigated in the light of illustrative examples, it is clear that such words do appear, but the tweets themselves are still primarily informative (although about economic topics).

\begin{tabular}{|c|c|c|c|c|c|c|c|c|}
\hline \multirow{2}{*}{$\begin{array}{l}\text { Country/ } \\
\text { Topic \# } \\
\text { Denmark }\end{array}$} & \multicolumn{8}{|c|}{ Selected keywords } \\
\hline & $\begin{array}{l}1 \\
2 \\
3 \\
4\end{array}$ & $\begin{array}{l}\text { congratulations } \\
\text { government } \\
\text { tax } \\
\text { good }\end{array}$ & $\begin{array}{l}\text { respect } \\
\text { like } \\
\text { growth } \\
\text { day }\end{array}$ & $\begin{array}{l}\text { thanks } \\
\text { think } \\
\text { education } \\
\text { morning }\end{array}$ & $\begin{array}{l}\text { great } \\
\text { well } \\
\text { better } \\
\text { fashion }\end{array}$ & $\begin{array}{l}\text { children } \\
\text { - } \\
\text { agreement } \\
\text { radical }\end{array}$ & $\begin{array}{l}\text { welcome } \\
\text { - } \\
\text { minister } \\
\text { beautiful }\end{array}$ & $\begin{array}{l}\text { world } \\
- \\
- \\
\text { home }\end{array}$ \\
\hline Ireland & $\begin{array}{l}1 \\
2\end{array}$ & $\begin{array}{l}\text { live } \\
\text { budget }\end{array}$ & $\begin{array}{l}\text { conference } \\
\text { jobs }\end{array}$ & $\begin{array}{l}\text { press } \\
\text { leaders }\end{array}$ & $\begin{array}{l}\text { president } \\
\text { questions }\end{array}$ & $\begin{array}{l}\text { day } \\
€\end{array}$ & $\begin{array}{l}\text { pm } \\
-\end{array}$ & - \\
\hline Sweden & $\begin{array}{l}1 \\
2 \\
3 \\
4 \\
5\end{array}$ & $\begin{array}{l}\text { Napolitano } \\
\text { right } \\
\text { good } \\
\text { council } \\
\text { change }\end{array}$ & $\begin{array}{l}\text { Italy } \\
\text { us } \\
\text { growth } \\
\text { ministers } \\
\text { decree }\end{array}$ & $\begin{array}{l}\text { year } \\
\text { well } \\
\text { people } \\
\text { president } \\
\text { law }\end{array}$ & $\begin{array}{l}\text { national } \\
\text { two } \\
\text { euro } \\
\text { press } \\
\text { government }\end{array}$ & $\begin{array}{l}\text { message } \\
\text { yesterday } \\
\text { great } \\
\text { meeting } \\
\text { parliament }\end{array}$ & $\begin{array}{l}\text { Europe } \\
\text { support } \\
\text { morning } \\
\text { release } \\
\text { - }\end{array}$ & $\begin{array}{l}\text { commitment } \\
- \\
\text { party } \\
- \\
\text { - }\end{array}$ \\
\hline
\end{tabular}

Sentiment analysis was used to further assess the characteristics of political Twitter use. If Twitter, given the short nature of its messages, is less appropriate for the promotion of economic ideas, would it be nonetheless rational to expect that the governments would strive to be positivistic? Especially in those countries in which the economic downturn caused significant economic and social distress? The sentiment analysis was used to identify the general nature of the tweets. It can also be expected that the more positivistic sentiment would appear in case of 'promotional' tweets, while if Twitter is used more to inform, state facts, the statements are likely to be more neutral. To perform sentiment analysis, the sentiment for each tweet was calculated, and the average score per country was calculated (Figure 1, Table 5).

Given the already determined predominantly informative nature of tweets, it was expected that the average would also be relatively 'neutral', although, in general, the positive words in the total sample (not divided by country, Figure 2) dominate the negative, since the average values are mildly positive (average values between 0.09 and 0.51 ). For comparison, in a study of satisfaction with home appliances, the average was 2.28 for coffee machines (Godnov \& Redek, 2018). In tourism, for example, it was 8.7 or 4-6 (for different attractions, see Godnov \& Redek, 2016a,b). This result is expected because consumers passionately share their opinions. In politics, especially in the case of providing information, passionate involvement is less expected. If governments were trying to promote 
(1) FIGURE 1

Sentiment analysis: average value of tweet sentiments per country a stance, the tweets would likely have a higher (absolute) value. Furthermore, if a study of political parties was done, it could be expected that opinions would be pronounced and consequently sentiments would be higher. The literature shows that political parties' Twitter activity is livelier, less neutral and used in election prediction (e.g. Tumasjan, Sprenger, Sandner, \& Welpe, 2010; Jungherr, 2013).
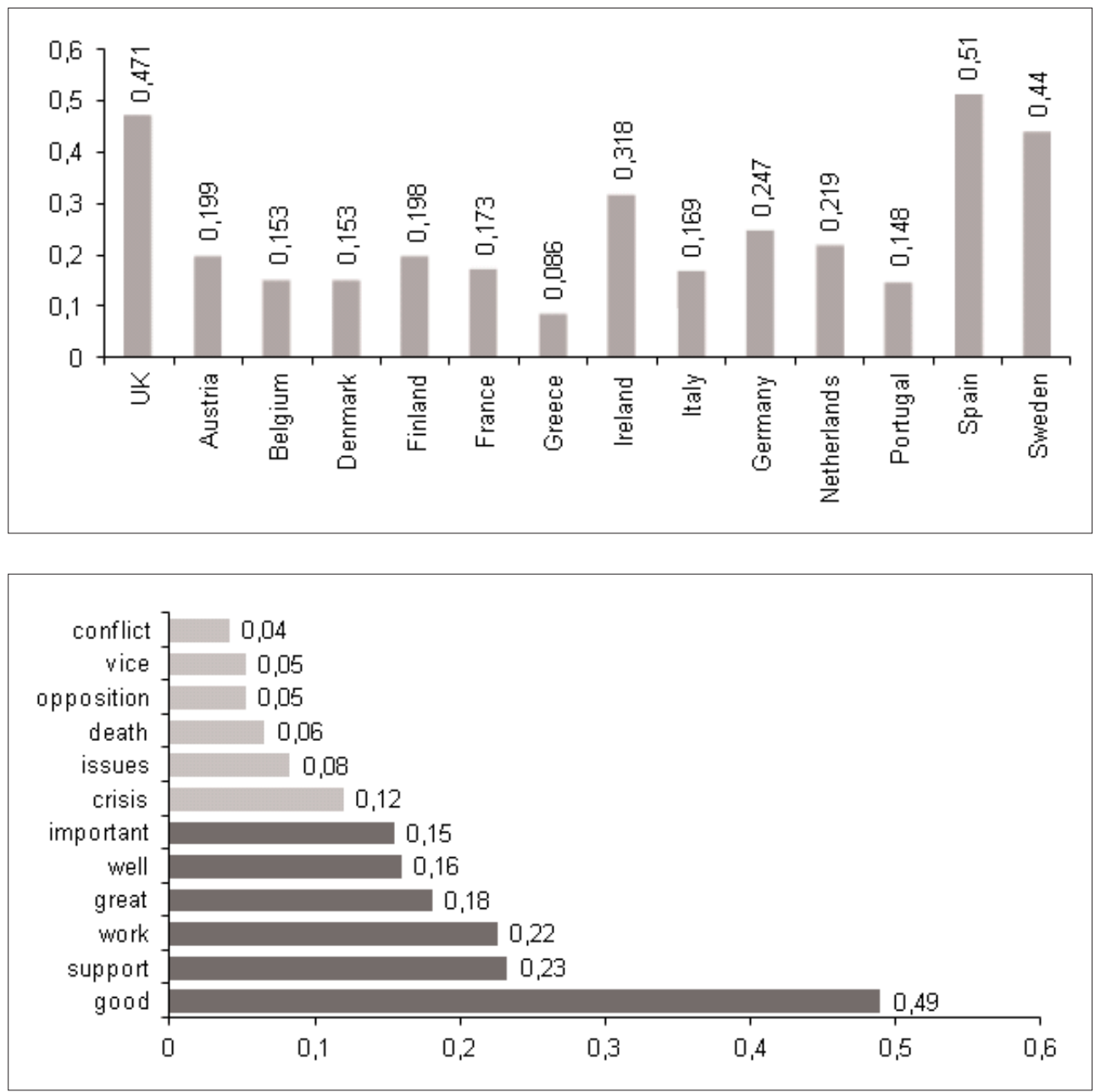

(i) FIGURE 2

Relative frequency

(\% of all words) of top 5 positive and negative words in the entire sample
Figure 3 presents a summary of the most common positive and negative words (neutrals were excluded). The most common positive word in the entire sample is 'good' with double the frequency of the next positive word, which is 'support', closely followed by 'work'. Moreover, 'great' and 'well' are quite common. The most common negative word is 'crisis', indicating the fact that the crisis was indeed an essential matter in the Twitter activity, although it should be noted that crisis can be linked with both political and economic crises. However, 
DRUŠ. ISTRAŽ. ZAGREB GOD. 27 (2018), BR. 4, STR. $691-711$

REDEK, T., GODNOV, U.: TWITTER AS A...

(1) TABLE 5

Most common positive and negative words by country the comparative neutrality of governmental Twitter activity can again be illustrated well if examples from tourism are used. There, among the most common positive words, terms such as astonishing, amazing, excellent and similar appear (Godnov \& Redek, 2016a,b; Godnov \& Redek, 2015), which have a much stronger emotional value. In this political setting, and especially also due to the prevailing informational purpose, much more neutral terms appear (Figure 3). However, positive average sentiment shows that positive words prevail over the negative. Moreover, even the negative words are not adjectives, which would express opinions, but are nouns, which reflect the nature of the politico-economic situation at the time, which was not the best due to the crisis.

There were also differences in the sentiments among countries, and the differences in the choice of words between countries are quite marked. Great Britain and Spain were the most positive, closely followed by Sweden and then Ireland.

An overview of common positive and negative words shows that, in general, among the positive words, words like 'good', 'support', 'great', 'work', 'progress', 'well' and similar dominate (Table 5).

\begin{tabular}{|c|c|c|c|c|c|c|c|}
\hline \multicolumn{2}{|l|}{ Country } & \multicolumn{6}{|l|}{ Common words } \\
\hline UK & $\begin{array}{l}\text { Positive } \\
\text { Negative }\end{array}$ & $\begin{array}{l}\text { support } \\
\text { conflict }\end{array}$ & $\begin{array}{l}\text { great } \\
\text { issues }\end{array}$ & $\begin{array}{l}\text { good } \\
\text { crisis }\end{array}$ & $\begin{array}{l}\text { work } \\
\text { opposition }\end{array}$ & $\begin{array}{l}\text { welcome } \\
\text { rape }\end{array}$ & $\begin{array}{l}\text { peace } \\
\text { urgent }\end{array}$ \\
\hline Austria & $\begin{array}{l}\text { Positive } \\
\text { Negative }\end{array}$ & $\begin{array}{l}\text { protection } \\
\text { warning }\end{array}$ & $\begin{array}{l}\text { thank } \\
\text { crisis }\end{array}$ & $\begin{array}{l}\text { welcome } \\
\text { condemns }\end{array}$ & $\begin{array}{l}\text { clear } \\
\text { issues }\end{array}$ & $\begin{array}{l}\text { freedom } \\
\text { opposition }\end{array}$ & $\begin{array}{l}\text { peace } \\
\text { death }\end{array}$ \\
\hline Belgium & $\begin{array}{l}\text { Positive } \\
\text { Negative }\end{array}$ & $\begin{array}{l}\text { congratulations } \\
\text { indiscreet }\end{array}$ & $\begin{array}{l}\text { good } \\
\text { death }\end{array}$ & $\begin{array}{l}\text { thank } \\
\text { controversy }\end{array}$ & $\begin{array}{l}\text { beautiful } \\
\text { dead }\end{array}$ & $\begin{array}{l}\text { great } \\
\text { attack }\end{array}$ & $\begin{array}{l}\text { work } \\
\text { opposition }\end{array}$ \\
\hline Denmark & $\begin{array}{l}\text { Positive } \\
\text { Negative }\end{array}$ & $\begin{array}{l}\text { good } \\
\text { radical }\end{array}$ & $\begin{array}{l}\text { well } \\
\text { crisis }\end{array}$ & $\begin{array}{l}\text { ready } \\
\text { tank }\end{array}$ & $\begin{array}{l}\text { like } \\
\text { fool }\end{array}$ & $\begin{array}{l}\text { thank } \\
\text { lure }\end{array}$ & $\begin{array}{l}\text { work } \\
\text { opposition }\end{array}$ \\
\hline Finland & $\begin{array}{l}\text { Positive } \\
\text { Negative }\end{array}$ & $\begin{array}{l}\text { gold } \\
\text { crisis }\end{array}$ & $\begin{array}{l}\text { support } \\
\text { issues }\end{array}$ & $\begin{array}{l}\text { work } \\
\text { exclusion }\end{array}$ & $\begin{array}{l}\text { peace } \\
\text { limits }\end{array}$ & $\begin{array}{l}\text { good } \\
\text { discrimination }\end{array}$ & $\begin{array}{l}\text { well } \\
\text { poverty }\end{array}$ \\
\hline France & $\begin{array}{l}\text { Positive } \\
\text { Negative }\end{array}$ & $\begin{array}{l}\text { great } \\
\text { crisis }\end{array}$ & $\begin{array}{l}\text { peace } \\
\text { condemns }\end{array}$ & $\begin{array}{l}\text { support } \\
\text { death }\end{array}$ & $\begin{array}{l}\text { solidarity } \\
\text { attack }\end{array}$ & $\begin{array}{l}\text { innovation } \\
\text { killed }\end{array}$ & $\begin{array}{l}\text { reform } \\
\text { recession }\end{array}$ \\
\hline Germany & $\begin{array}{l}\text { Positive } \\
\text { Negative }\end{array}$ & $\begin{array}{l}\text { support } \\
\text { crisis }\end{array}$ & $\begin{array}{l}\text { good } \\
\text { death }\end{array}$ & $\begin{array}{l}\text { work } \\
\text { condemns }\end{array}$ & $\begin{array}{l}\text { important } \\
\text { emergency }\end{array}$ & $\begin{array}{l}\text { peace } \\
\text { debt }\end{array}$ & $\begin{array}{l}\text { great } \\
\text { opposition }\end{array}$ \\
\hline Greece & $\begin{array}{l}\text { Positive } \\
\text { Negative }\end{array}$ & $\begin{array}{l}\text { work } \\
\text { crisis }\end{array}$ & $\begin{array}{l}\text { timely } \\
\text { debt }\end{array}$ & $\begin{array}{l}\text { confidence } \\
\text { problems }\end{array}$ & $\begin{array}{l}\text { great } \\
\text { hard }\end{array}$ & $\begin{array}{l}\text { support } \\
\text { loss }\end{array}$ & $\begin{array}{l}\text { sustainable } \\
\text { struggle }\end{array}$ \\
\hline Ireland & $\begin{array}{l}\text { Positive } \\
\text { Negative }\end{array}$ & $\begin{array}{l}\text { work } \\
\text { shatter }\end{array}$ & $\begin{array}{l}\text { well } \\
\text { debt }\end{array}$ & $\begin{array}{l}\text { progress } \\
\text { crisis }\end{array}$ & $\begin{array}{l}\text { great } \\
\text { issues }\end{array}$ & $\begin{array}{l}\text { important } \\
\text { death }\end{array}$ & $\begin{array}{l}\text { reform } \\
\text { difficult }\end{array}$ \\
\hline Italy & $\begin{array}{l}\text { Positive } \\
\text { Negative }\end{array}$ & $\begin{array}{l}\text { good } \\
\text { crisis }\end{array}$ & $\begin{array}{l}\text { work } \\
\text { tragedy }\end{array}$ & $\begin{array}{l}\text { well } \\
\text { death }\end{array}$ & $\begin{array}{l}\text { right } \\
\text { emergency }\end{array}$ & $\begin{array}{l}\text { great } \\
\text { bad }\end{array}$ & $\begin{array}{l}\text { support } \\
\text { seriousness }\end{array}$ \\
\hline $\begin{array}{l}\text { Nether- } \\
\text { lands }\end{array}$ & $\begin{array}{l}\text { Positive } \\
\text { Negative }\end{array}$ & $\begin{array}{l}\text { work } \\
\text { fraud }\end{array}$ & $\begin{array}{l}\text { good } \\
\text { crisis }\end{array}$ & $\begin{array}{l}\text { better } \\
\text { vice }\end{array}$ & $\begin{array}{l}\text { support } \\
\text { missed }\end{array}$ & $\begin{array}{l}\text { sustainable } \\
\text { illegal }\end{array}$ & $\begin{array}{l}\text { important } \\
\text { criminal }\end{array}$ \\
\hline Portugal & $\begin{array}{l}\text { Positive } \\
\text { Negative }\end{array}$ & $\begin{array}{l}\text { honored } \\
\text { death }\end{array}$ & $\begin{array}{l}\text { award } \\
\text { solemn }\end{array}$ & $\begin{array}{l}\text { honor } \\
\text { vice }\end{array}$ & $\begin{array}{l}\text { innovative } \\
\text { mar }\end{array}$ & $\begin{array}{l}\text { prize } \\
\text { oversight }\end{array}$ & $\begin{array}{l}\text { supreme } \\
\text { crisis }\end{array}$ \\
\hline Spain & $\begin{array}{l}\text { Positive } \\
\text { Negative }\end{array}$ & $\begin{array}{l}\text { good } \\
\text { vice }\end{array}$ & $\begin{array}{l}\text { available } \\
\text { crisis }\end{array}$ & $\begin{array}{l}\text { work } \\
\text { difficult }\end{array}$ & $\begin{array}{l}\text { support } \\
\text { corruption }\end{array}$ & $\begin{array}{l}\text { reform } \\
\text { problems }\end{array}$ & $\begin{array}{l}\text { thank } \\
\text { hard }\end{array}$ \\
\hline Sweden & $\begin{array}{l}\text { Positive } \\
\text { Negative }\end{array}$ & $\begin{array}{l}\text { good } \\
\text { issues }\end{array}$ & $\begin{array}{l}\text { important } \\
\text { issue }\end{array}$ & $\begin{array}{l}\text { well } \\
\text { opposition }\end{array}$ & $\begin{array}{l}\text { great } \\
\text { worrying }\end{array}$ & $\begin{array}{l}\text { welcome } \\
\text { concern }\end{array}$ & $\begin{array}{l}\text { peace } \\
\text { crisis }\end{array}$ \\
\hline
\end{tabular}


DRUŠ. ISTRAŽ. ZAGREB GOD. 27 (2018), BR. 4 STR. $691-711$

REDEK, T., GODNOV, U.: TWITTER AS A...
While among the negative, 'crisis' is the most present word and is among the most common negative words in all countries, except in Belgium. 'Debt' is quite common, also related to the crisis, as are words like 'worry' and 'struggle'. Among the less economic but more political words, primarily words of death and conflict are present. It can be concluded that, overall, the negative side of the communication was dominated by the economic crisis and reform in the domestic economy, while the global negative influences emerged from conflict situations in Syria, the Middle East, and North Africa.

These differences in the sentiments between countries could generally be explained by three main determinants. First, the nature of the tweets. Where informative tweets prevail to an even larger extent than on average, the presence of more positive words would be lower, while more neutral ones would prevail. Second, the politico-economic momentum, which is despite the 'common crisis impact' different across Europe, impacted the most pronounced political issues. Last, cultural impact is also essential. In general, the level of confidence and optimism was identified in the literature as lower in the Mediterranean (Fischer \& Chalmers, 2008), and young people are also pessimistic in the Netherlands, France, Belgium, Germany, Austria (primarily due to crisis-related lack of opportunities, EBU, 2016).

To summarise the main findings thus far, we can say that during the crisis Twitter was used primarily to inform, state facts, and not to actively promote economic agendas.

However, at the time, the development or penetration of this social medium differed across countries. Therefore, even if the nature of the Twitter activity is similar in essence in all countries, this difference in the penetration is evident from the significantly different number of tweets among countries. Thus, finally, we examine whether the development of the Twitter use or the spread of the platform (Table 1) impacted the nature of the communication. The extent of the Twitter use is related to both internet penetration in general (Pearson correlation coefficient is 0.44 ) as well as the number of internet users, which defines the size of the 'voters' targeted (correlation 0.68 ). We also verified the relationships between Twitter use and the depth of the development of internet skills in a country (Table 1, Figure 3 ).

There is essentially no relationship between the percentage of people using the web to search (correlation is 0.05), which is expected since this percentage is uniformly high. The percentage of those that have used the web to post comments, etc., and the number of tweets is more closely related, the correlation coefficient is 0.25 . It is nonetheless weaker than would be expected, since it is an indicator of the gener- 
(1) FIGURE 3

Relationship between the number of tweets, number of internet users and internet penetration al mode of web use in a country. However, it seems that at the time, the size of the market was the most critical determinant of Twitter activity for political purposes. Moreover, since the primary purpose was to inform, for which feedback is not expected, the weaker link is also understandable.

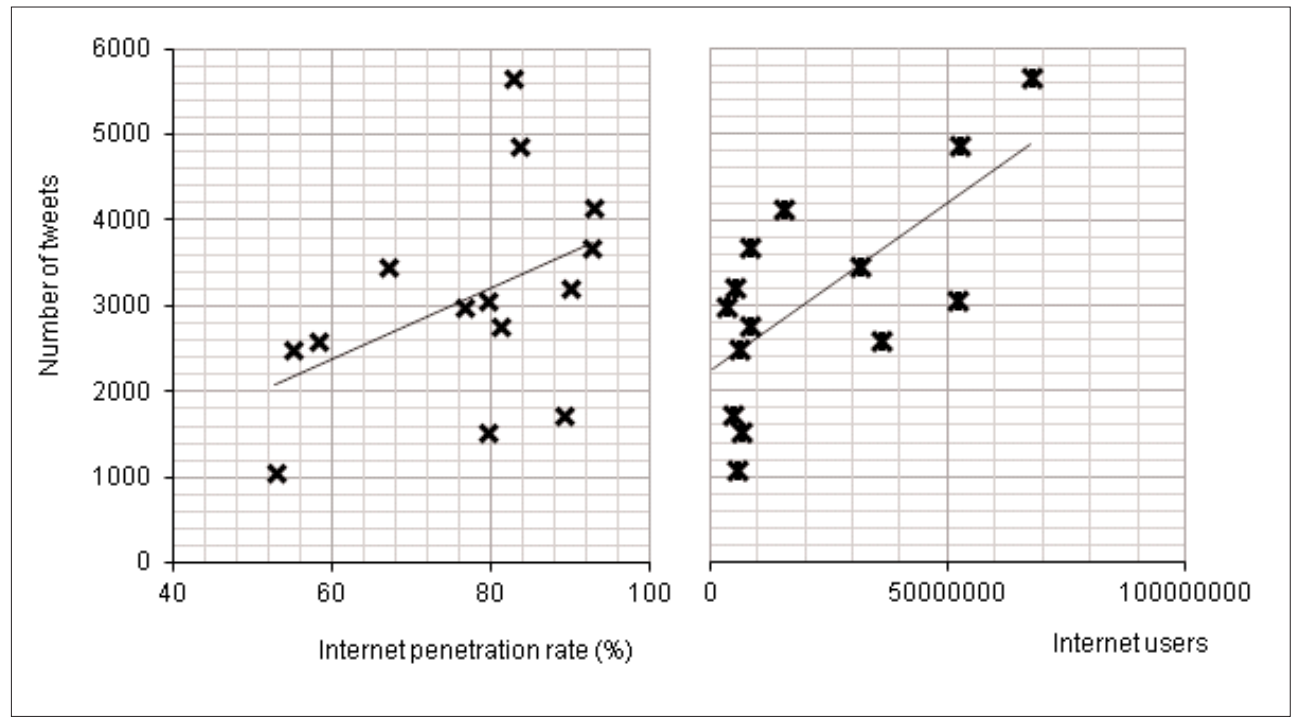

Data: Table 1.

\section{CONCLUSION}

The purpose of this article was to analyse the nature of political Twitter communication of governments in the EU15. Following the research questions, we showed that:

(1) Twitter was used as a tool of communication by politicians, but primarily to inform and not actively promote political views or economic agendas. Even in economics-related content, the tweets primarily inform the public about them, not promote them. This was so also in the countries where the crisis struck hardest. However, this situation can be expected to change as Twitter becomes even more popular, and its penetration stronger.

(2) As a consequence of the informative nature (and in relation to the second research question), the sentiments are relatively neutral, as expected. The positive aspects are marked by dedication- and motivation-related words, while the negative emotions arise due to the economic downturn and global conflicts.

(3) Third, we showed that the extent of Twitter 'promotional' use also depends on the size of the 'Twitter market', which is also related to the general internet culture of the country. In relation to the fact that at the moment of investigation Twitter 
DRUŠ. ISTRAŽ. ZAGREB GOD. 27 (2018), BR. 4 STR. $691-711$

REDEK, T., GODNOV, U. TWITTER AS A...

\section{REFERENCES}

was not yet so popular, but taking into account this positive link between Twitter use and penetration, in the future, the nature of political communication will continue to change.

It should also be noted that this paper has made several contributions to the field. First, it extends the knowledge about the use of social networks and the content of political communication via Twitter to a comparative scale. Next, a comparative analysis across 14 countries was done, which is to the best of our knowledge unique in the literature. Third, the computational linguistics analysis (keywords, keywords in context, and sentiment analysis) of political use of Twitter in the comparative setting is, to the best of our knowledge, also a novelty in the political literature.

The paper also faced some limitations, which open challenges for future research. In addition to these challenges for the future, a comparative analysis of European politics could also address the problems of networks in social media, including Twitter, and the strength and development of such networks on possible election outcomes in a comparative manner as well as study of the development of the networks and the content of communication in the networks. Country-level or case-level analyses that already exist could motivate such comparative research (Xu, Sang, Blasiola, \& Park, 2014, for a Wisconsin election; Kim, Lee, \& Park, 2016, for Korea), which would further aid in understanding the nature of political differences in the European context.

Aiken, M., \& Balen, S. (2011). An analysis of Google translate accuracy. Translation Journal, 16(2). Available at http://translationjournal.net/ journal/56google.htm

Auvinen, A.-M. (2011). Social media - the new power of political influence. Brussels: Centre for European studies. Available at http://thinking europe.eu/sites/default/files/publication-files/kansio-digital_democracy__final_en.pdf

Bahtar, A. Z., \& Muda, M. (2016). The impact of User - Generated Content (UGC) on product reviews towards online purchasing - A conceptual framework. Procedia Economics and Finance, 37, 337-342. https://doi.org/10.1016/S2212-5671(16)30134-4

Beevolve (2012). An exhaustive study of Twitter users across the world. Available at http://www.beevolve.com/twitter-statistics/\#a3

Blei, D. M. (2012). Probabilistic topic models. Communications of the ACM, 55(4), 77-84. https://doi.org/10.1145/2133806.2133826

Brants, K., \& Voltmer, K. (2011). Introduction: Mediatization and decentralization of political communication. In K. Brants \& K. Voltmer (Eds.), Political communication in postmodern democracy (pp. 1-18). London: Palgrave McMillan. https://doi.org/10.1057/9780230294783_1 
DRUŠ. ISTRAŽ. ZAGREB

REDEK, T., GODNOV, U.: TWITTER AS A... GOD. 27 (2018), BR. 4, STR. $691-711$

Chen, E. (2011). Introduction to latent Dirichlet allocation. Microsoft research. Available at http://blog.echen.me/2011/08/22/introduction-tolatent-dirichlet-allocation/.

Coughlin, D. (2003). Correlating automated and human assessments of machine translation quality. Microsoft research. Available at http://www. mt-archive.info/MTS-2003-Coughlin.pdf

Dahlgren, P. (2014). Participation and alternative democracy: Social media and its contingencies. In P. Serra, E. J. M. Camilo, \& G. Gonçalves (Eds.), Political participation and web 2.0 (pp. 61-85). Covilha: Livros LabCom. Available at http://www.livroslabcom.ubi.pt/pdfs/ 20140410-2014_political_participation_and_web2.0.pdf

DeHaaff, M. (2010). Sentiment analysis. Hard, but worth it. Available at http://customerthink.com/sentiment_analysis_hard_but_worth_it/

EBU (2016). Generation What. Young people and optimism - A pan-European view. EBU. Available at https://www.ebu.ch/files/live/sites/ebu/ files/Publications/Reports/Generation $\%$ 20What $\% 20-\% 20$ Young $\%$ 20People $\% 20$ and $\%$ 20Optimism $\% 20-\% 20 \mathrm{~A} \% 20$ Pan-European $\% 20$ View.pdf

EMarketer (2013). Social networking reaches nearly one in four around the world. Available at http://www.emarketer.com/Article/Social-NetworkingReaches-Nearly-One-Four-Around-World/1009976.

Eurostat $(2015,2018)$. Eurostat - Online database. Available at http://epp. eurostat.ec.europa.eu/portal/page/portal/statistics/themes

Fischer, R., \& Chalmers, A. (2008). A meta-analytical investigation of optimism levels across 22 nations. Personality and Individual Differences, 45, 378-382. https://doi.org/10.1016/j.paid.2008.05.008

GlobalWebIndex (2013). Twitter now the fastest growing social platform in the world. Available at http://blog.globalwebindex.net/twitter-now-thefastest-growing-social-platform-in-the-world/

Godnov, U., \& Redek, T. (2015). Croatian tourism evaluation: The lessons from the on-line peer assessments of selected tourist facilities. In 7th International conference "EU future perspectives: innovation entrepreneurship and economic policy", Pula, 21st-23rd May 2015: book of abstracts (p. 76).

Godnov, U., \& Redek, T. (2016a). Analiza mnenj obiskovalcev o turistični ponudbi v Ljubljani [Analysis of the tourist offer in Ljubljana]. Economic and Business Review, 18(4), 5-22. https://doi.org/10.15458/ 85451.29

Godnov, U., \& Redek, T. (2016b). Application of text mining in tourism: Case of Croatia. Annals of Tourism Research, 58, 162-166. https://doi.org/ 10.1016/j.annals.2016.02.005

Greenfield, D. (2013). The rise of mediacracy. Daniel Greenfield blog. Available at http://sultanknish.blogspot.com/2013/12/rise-of-mediacracy.html. Grossman, G. M., \& Helpman, E. (2001). Special interest politics. Cambridge MA: MIT Press.

Hofmesiter, W., \& Grabow, K. (2011). Political parties. Functions and organisation in democratic societies. Bonn: Konrad Adenauer Stiftung. Available at http://www.kas.de/wf/doc/kas_7671-1442-2-30.pdf?1209 
DRUŠ. ISTRAŽ. ZAGREB GOD. 27 (2018), BR. 4, STR. $691-711$

REDEK, T., GODNOV, U.: TWITTER AS A...
Hu, M., \& Liu, B. (2004). Opinion extraction and summarization on the web. AAAI'06 proceedings of the 21st national conference on Artificial intelligence - Volume 2, pp. 1621-1624.

Internet World Stats (2016). Internet usage in Europe. Available at http:// www.internetworldstats.com/stats4.htm\# europe.

Jungherr, A. (2013). Tweets and votes, a special relationship: The 2009 federal election in Germany. Proceedings of the 2nd workshop on Politics, elections and data (PLEAD 13), pp. 5-14. https://doi.org/10.1145/250 8436.2508437

Khan, G. H., Yoon, H. Y., Kim, J., \& Park, H. W. (2014). From e-government to social government: Twitter use by Korea's central government. Online Information Review, 38(1), 95-113. https://doi.org/10.1108/OIR09-2012-0162

Kim, J., Lee, Y.-O., \& Park, H. W. (2016). Delineating the complex use of a political podcast in South Korea by hybrid web indicators: The case of the Nakkomsu Twitter network. Technological Forecasting and Social Change, 110, 42-50. https://doi.org/10.1016/j.techfore.2015.11.012

Los Angeles Times (2013). INFOGRAPHIC: What country has highest number of active Twitter users? Available at http://articles.latimes.com/ 2013/nov/21/news/la-sh-twitter-users-graphics-20131121.

McGregor, S. C., Mourão, R. R., \& Molyneux, L. (2017). Twitter as a tool for and object of political and electoral activity: Considering electoral context and variance among actors. Journal of Information Technology \& Politics, 14(2), 154-167. https://doi.org/10.1080/19331681. 2017.1308289

Merrill, T., Latham, K., Santalesa, R., \& Navetta, D. (2011). Social media: The business benefits may be enormous, but can the risks - reputational, legal, operational - be mitigated? Information Law Group. Available at http://old.findinet.nl/čuploads/newsModule/ace_socialmedia111118.pdf MVFGlobal (2014). MVF Global country reports. Available at http://www. mvfglobal.com/

NERI (2013). How did austerity affect Ireland? Dublin: Nevin Economic Research Institute. Available at http://www.nerinstitute.net/research/ how-did-austerity-affect-ireland/

Oxfam (2013). The true cost of austerity and inequality. The Portugal case. Oxfam case study. Available at http://www.oxfam.org/sites/www.oxfam. org/files/cs-true-cost-austerity-inequality-portugal-120913-en.pdf

Posner, M., Wallace, A., \& Borovsky, Z. (2012). Very basic strategies for interpreting results from the topic modeling tool. Miriam Posner's Blog (blog). October 29, 2012. Available at http://miriamposner.com/blog/ very-basic-strategies-for-interpreting-results-from-the-topic-modeling-tool/

Redek, T., \& Godnov, U. (2018). Text-mining for business intelligence: An analysis of preferences of Chinese travellers. Presented at the EBR conference at the Faculty of Economics University of Ljubljana. Available at http://www.ebrjournal.net/ocs/index.php/ebr2014/EBR2017/paper/ view/196/130

Reuters (2012). Factbox: Greek austerity and reform measures. Available at http://www.reuters.com/article/2012/02/19/us-greece-austerity-idUS TRE81I05T20120219 
DRUŠ. ISTRAŽ. ZAGREB GOD. 27 (2018), BR. 4, STR. $691-711$

REDEK, T., GODNOV, U. TWITTER AS A...
Smith, K. N. (2011). Social media and political campaigns. University of Tennessee Honours Theses. Knoxville: University of Tennessee. Available at http://trace.tennessee.edu/cgi/viewcontent.cgi?article $=2442 \&$ context $=$ utk_chanhonoproj

Stieglitz, S., \& Dang-Xuan, L. (2013). Social media and political communication - A social media analytics framework. Social Network Analysis and Mining, 3(4), 1277-1291. https://doi.org/10.1007/s13278-0120079-3

Tumasjan, A., Sprenger, T. O., Sandner, P. G., \& Welpe, I. M. (2010). Predicting elections with Twitter: What 140 characters reveal about political sentiment association for the advancement of artificial intelligence. Available at https://www.aaai.org/ocs/index.php/ICWSM/ICWSM10/ paper/viewFile/1441/1852

Twiplomacy (2017). Twiplomacy study 2017. Executive summary. Available at http://twiplomacy.com/blog/twiplomacy-study-2017/

Twitter (2012). 2012 on Twitter. Golden Twits. Available at https://2012. twitter.com/en/golden-tweets.html

Vesnic-Alujevic, L. (2013). Members of the European Parliament Online: The use of social media in political marketing. Centre for European Studies. Available at http://www.martenscentre.eu/sites/default/files/pub lication-files/political-marketing-and-social-media.pdf

Vongsoasup, N., \& Iijima, J. (2016). What is a role of Twitter in Thai political communication? PACIS 2016 Proceedings. Available at https://aisel. aisnet.org/pacis2016/356

Wickman, S. B. (2013). Belgium. A country study. Scotts Valley (US): CreateSpace Independent Publishing Platform.

Xu, W. W., Sang, Y., Blasiola, S., \& Park, H. W. (2014). Predicting opinion leaders in Twitter activism networks. The case of the Wisconsin recall election. American Behavioral Scientist, 58(10), 1278-1293. https://doi. org/10.1177/0002764214527091

Zhang, C., Wang, H., Liu, Y., Wu, D., Lia, Y., \& Wang, B. (2008). Automatic keyword extraction from documents using conditional random fields. Journal of Computational Information Systems, 4(3), 1169-1180. Available at https://core.ac.uk/download/pdf/11884499.pdf

\section{Twitter kao politički alat u zemljama EU-a tijekom ekonomske krize: dubinska komparativna analiza teksta}

Tjaša REDEK

Ekonomski fakultet, Sveučilište u Ljubliani, Ljubljana

Uroš GODNOV

Fakultet za menadžment, Sveučilište Primorska, Koper

Rad analizira kako političari rabe Twitter, a osobito je li bio aktivno upotrijebljen tijekom ekonomske krize radi promicanja ekonomskih programa ili pak samo radi 
DRUŠ. ISTRAŽ. ZAGREB GOD. 27 (2018), BR. 4 STR. $691-711$

REDEK, T., GODNOV, U.: TWITTER AS A... iz 15 zemalja prikuplieno je, analizirano i protumačeno kvalitativnom analizom podataka (dubinske analize teksta) računalnom lingvistikom te Uz pomoć $R$ statističkih paketa.

Rezultati pokazuju da se Twitter rabi prije svega za informiranje. Samo u odabranim slučajevima taj je alat poslužio i aktivnijem promicanju gospodarskih programa. Članak smatramo doprinosom istraživanju područja političke komunikacije u Europi, jer uz pomoć metoda dubinske analize teksta daje širok analitički i komparativni pregled aktivnosti na Twitteru u političke svrhe.

Ključne riječi: Twitter, politika, promicanje reformi, računalna lingvistika, dubinska analiza teksta, cross-country analiza

\section{(c) $(1)(8)$}

Međunarodna licenca / International License:

Imenovanje-Nekomercijalno / Attribution-NonCommercial 